\title{
References
}

Holst, N. 1886: Berättelse om en år 1880 i geologiskt syfte företagen resa till Grönland. Sveriges geol. Unders. C, 81.

Jessen, A. 1896 Geologiske Iagttagelser. In Opmaalingsexpeditionen til Julianehaabs-Distrikt 1894. Meddr Grønland 16, 123-169.

Kelly, M. 1973: The marine limit in Julianehåb district, south Greenland and its isostatic implications. Grønlands geol. Unders., Unpubl. rep., 11 pp.

Kelly, M. 1975a: A provisional outline of the Quaternary geology of the Frederikshåb area, West Greenland. Grønlands geol. Unders., Unpubl. rep., 10 pp.

Kelly, M. 1975b: A note on the implications of two radiocarbon dated samples from Qaleragdlit imâ, South Greenland. Bull. geol. Soc. Denmark 24, 21-26.

Department of Environmental Sciences, University of Lancaster,

Bailrigg,

Lancaster LAI $4 Y Q$,

U.K.

\section{Current research in the Ilímaussaq region, South Greenland}

\section{Compiled by John Rose-Hansen and Henning Sørensen}

The 1976 season's field work in the Ilimaussaq region was concerned with the lujavrites of the south-eastern part of the Ilimaussaq alkaline intrusion, the uranium-rich rocks along the intrusion's northern contact, the environmental geochemistry and ecology of the Narssaq region, and the Narssaq intrusion situated to the west of the Ilímaussaq intrusion. Each of these projects is briefly discussed below.

\section{Field mapping of green aegirine lujavrite (Henning Bohse)}

Detailed mapping on a scale of 1:5000 of an area between the two branches of the upper part of Lakseelv in the southern half of the Ilimaussaq alkaline intrusion was carried out. The work was a continuation of mapping initiated in 1974 (Bohse, in Bohse et al., 1975). No essentially new developments in the understanding of the geology of the area resulted from this summer's field work.

Further attention was given to the globular natrolite-analcime nodules mentioned in Bohse et al. (1975) and it became clear that these nodules are genetically associated with partly assimilated inclusions of naujaite in lujavrite. Numerous lujavritic pegmatites up to $10 \mathrm{~m}$ wide and with big rusty steenstrupine crystals occur in the area. These pegmatites become more common towards the east. 
Two sets of faults occur, one trending between $170^{\circ}$ and $180^{\circ}$ showing right-lateral displacements and the other trending between $50^{\circ}$ and $70^{\circ}$ showing both normal and left-lateral displacements.

In the eastern parts of the area the rocks are more or less heavily metasomatically altered, generally displaying small-scale folding. This folding is interpreted as a plastic deformation of rocks softened because of heating and gas permeation during the metasomatic alteration of the rocks.

\section{Uranium-rich albitites from the northern contact of the Ilimaussaq alkaline intru- sion (John Rose-Hansen, Sven Karup-Møller, Emil Sørensen \& Henning Sørensen)}

In the summer of 1974 small outcrops of strongly radioactive rocks were found at an altitude of about $800 \mathrm{~m}$ in the steep, scree-covered north wall of the Narssaq Elv valley. The radioactive rock occurs in the foot wall of the Ilímaussaq mountain and is situated in or very close to the contact between the rocks of the Ilímaussaq intrusion and the overlying basaltic lavas.

The rocks of the intrusion are mainly hidden by lava talus at this place but a few outcrops of pulaskitic to foyaitic rocks veined by lujavrite indicate that the top of the intrusion at this locality consists of these rock types.

The radioactive rocks are seen in contact with pulaskite/foyaite at an altitude of $c .770 \mathrm{~m}$. They are rust-coloured having crusts of black maganiferous material. They have in places a strongly sheared appearance and may thus represent mineralised zones of deformation. There are, however, also massive-looking mineralised rocks.

The radioactive rocks may be characterised as albitites which are very heterogeneous with respect to textures and mineralogy. The following minerals have been observed so far: albite, microcline, arfvedsonite, aegirine, a fibrous blue amphibole, brown biotite, green chlorite, one or more carbonate minerals, neptunite, opaque minerals which have not yet been identified, apatite, brown steenstrupine-looking minerals, brown and black pigmentary material, fluorite, and several unidentified minerals. Fission track studies have shown that the uranium is disseminated in the rock and associated with minute grains of pigmentary material.

Some of the mineralised rocks resemble the arfvedsonite-aegirine-bearing albititic vein rocks observed within the intrusion, others are very rich in carbonate minerals, besides biotite, chlorite or blue amphibole and do not recall any of the vein rocks of the intrusion. They resemble radioactive veins observed to the east of the intrusion (Hansen, 1968). Quartz has been observed in one sample.

A reconnaissance study of the foot wall of the Ilimaussaq mountain was undertaken in 1976. A zone of radioactive rocks could be traced along the scree slope for a distance of about $1.5 \mathrm{~km}$ between 750 and $1000 \mathrm{~m}$ altitude. The zone appears to be almost vertical, the width varying from 5 to $10 \mathrm{~m}$.

The first sample collected in 1974 contained 1.70 per cent $U, 95 \mathrm{ppm}$ Th and 11.7 per cent $\mathrm{Nb}_{2} \mathrm{O}_{5}$. Preliminary uranium determinations on samples collected in 1976 carried out by the delayed neutron method and by wet chemical methods show much lower contents of uranium varying from $c .180 \mathrm{ppm}$ to more than $3000 \mathrm{ppm} \mathrm{U}$, with contents of $180-400 \mathrm{ppm}$ $\mathrm{U}$ typical for analysis carried out on bulk samples. All samples are poor in thorium. A detailed study of this mineralisation is now in progress. 
Environmental geochemistry and ecology (Christian Overgaard Nielsen, John Rose-Hansen \& Henning Sørensen)

This project undertaken jointly by GGU and the Danish Natural Science Research Council (SNF) was initiated in 1974 (Bohse et al., 1975; Nielsen et al., 1976).

The first three-year phase of field investigations was concluded in 1976. The field work comprised the following activities:

(1) A study of the Quaternary geology of the Narssaq area (see report by Funder \& Andsbjerg, below).

(2) Continuous registration of a number of climatological and hydrological parameters in selected localities (Niels P. Christensen, Jens Jørgensen \& Lars H. Nielsen, see report by Christensen, below).

(3) A study of weathering and soils. The activities mentioned in Nielsen et al. (1976) have been continued (Carsten Langtofte Larsen \& Leo Nielsen).

(4) Marine biology. The sampling of the marine fauna was continued and extended to cover also the fjord Sermilik (Martin Munk Hansen).

(5) Botanical investigations were concentrated on the Dyrnæs-Kvanefjeld area (Jon Feilberg).

(6) Limnology. The limnological investigations initiated in 1975 were concluded in 1976 during the period 17 May to 1 October, that is from before the ice covering the lakes melted and until the primary biological production period was decreasing. The collections comprised samples of water to be analysed for nutrative salts in addition to samples of flora and fauna. They will constitute the basis of a general ecological description of the limnic conditions in the area. From several localities both within and outside the Ilímaussaq intrusion samples of the invertebrate fauna have been collected and will be incorporated in the programme of chemical analysis. The programme in 1976 was extended to include $\mathrm{C}^{14}$ determination of the primary production and quantitative zooplankton sampling in the various localities.

Concurrently with this work a dynamic ecological programme has been carried out throughout the season with the aim of establishing the most important factors for biological development in an area of this kind (Henrik Mosegaard, Peter Mæhl \& Bent Henning Nielsen).

(7) Sampling for chemical analysis. As in earlier years, a large number of samples of all parts of the natural environment of the Narssaq region were collected. Special emphasis in 1976 was put on collection of samples of the precipitation. The geological samples are currently being studied mineralogically and petrographically, the biological samples are studied taxonomically and experimentally. All kinds of samples are being chemically analysed.

\section{Quaternary geology of the Narssaq area (Svend Funder \& Jan Andsbjerg)}

The aim of the work was to provide detailed maps of the Quaternary geology of some selected areas, and to trace the former routes of glacier movement and transportation, in particular the spreading of boulders of the characteristic rock types from the Ilímaussaq intrusion in areas to the west of their outcrop. 
A general survey of the Quaternary geology and stratigraphy in this part of Greenland has been presented by Weidick (1963); some preliminary results of our work will be mentioned here.

Generally, the area is one of glacial erosion, not of accumulation. Glacial deposits are sparse and occur most frequently as ablation till rich in boulders forming a thin and discontinuous cover over the glacially sculptured bedrock surface. Boulder and stone counts were made in this type of deposit in all parts of the area and the finer fractions were sampled for later laboratory analysis. The picture emerging from the counts shows a very irregular distribution of the erratics, the boulder 'communities' are always dominated by a large local component. Boulders from the Ilimaussaq intrusion have been observed up to $20 \mathrm{~km}$ to the west of their present outcrop, but locally they may be absent in the intervening areas. Along the north side of the Kangerdluarssuk fjord they are very sparse whereas they occur frequently on the south side of the adjacent Tunugdliarfik fjord. The great variation in composition of the boulder communities seems to reflect poor mixing in the transporting body of ice. This observation is consistent with the general picture of the Ice Age glacial regime, as obtained from other types of evidence.

Glacial striations and erratics have been observed up to $1200 \mathrm{~m}$ above sea level on the sides of the Nákâlâq mountain providing a minimum estimate for the thickness of the ice cover over the area. At all altitudes the striations show dependence on the local topography, and appear to branch off from the major fjord basins - the basins of Tunugdliarfik and Bredefjord - at acute angles. They therefore seem to indicate expanded fjord and valley glaciers rather than the expansion of the Inland Ice.

Also the local topography reflects restricted glaciation rather than ice sheet erosion. A very characteristic geomorphological feature is 'overflow' troughs and valleys which occur abundantly in the areas along the major fjords. The troughs and valleys are characterised by a steep cirque-like head wall at the top of which is found a col with traces of heavy glacial erosion. Striations show that they were formed by glacier tongues flowing over from the ice streams in the major fjords. The Kangerdluarssuk fjord with its tributary valleys and the Narssaq valley were formed by this process.

In some areas, notably the Narssaq Elv valley, crossing striations indicate a complex succession of glacier tongues flowing over from different sources during the final period of withering of the ice streams in Bredefjord and Tunugdliarfik.

Weidick (1972) noted that the low altitudes of marine limits generally observed in the region may indicate slight isostatic rebound, and a light burden of ice over the area in the Upper Wisconsin - Weichselian. Earlier observations as well as those made by us have shown the marine limit in the Narssaq area to be $40-50 \mathrm{~m}$ above sea level. A few samples of organic sediments in lakes isolated from the fjords during isostatic land upheaval are currently being $\mathrm{C}^{14}$ dated and these are expected to yield some information on the process of isostatic upheaval and on conditions during the Ice Age.

\section{The use of dataloggers (Niels P. Christensen)}

In 1975 dataloggers of the type Aanderaa DL- 1 were established in the Narssaq Elv valley and in Kangerdluarssuk fjord in order to record a number of climatological and hydrological parameters throughout the whole year (Nielsen et al., 1976). 
A datalogger consists essentially of a battery driven tape recorder onto which 11 sensors can be connected. A 12th channel is an internal test channel situated within the recording unit. Series of recordings are made in the 12 channels in succession, each series being initiated by signals from a quartz clock. The series of measurements are repeated at intervals of two hours during a period of up to one year, which is the optimal working range of the tape and the batteries.

As a new approach to measuring hydrological parameters, pressure transducers are used in measuring the precipitation in the two areas and the water stage of four of the streams. The pressure transducers were put into operation in late summer 1976.

The essential part of a transducer is a membrane which , by means of an electrical current, registers the pressure of the overlying column of water. The output signal is a relative change in electrical resistance, which is measured by a Wheatstone bridge in the recording unit. The signal is turned into a binary number and recorded on ordinary tape.

The transducers used in the streams are constructed as shown in fig. 17. The units are held in position in the stream by a $1 \frac{1}{2}$ inch iron water pipe, which also protects the cable and a thin polyethylene tube. The polyethylene tube, which leads from the rear side of the membrane to the top of a c. $3 \mathrm{~m}$ high metal pole on the river bank, is used to compensate for variations of the atmospheric pressure (fig. 18).

Fig. 17. A simplified sketch of a pressure transducer unit used in the Narssaq project, South Greenland.

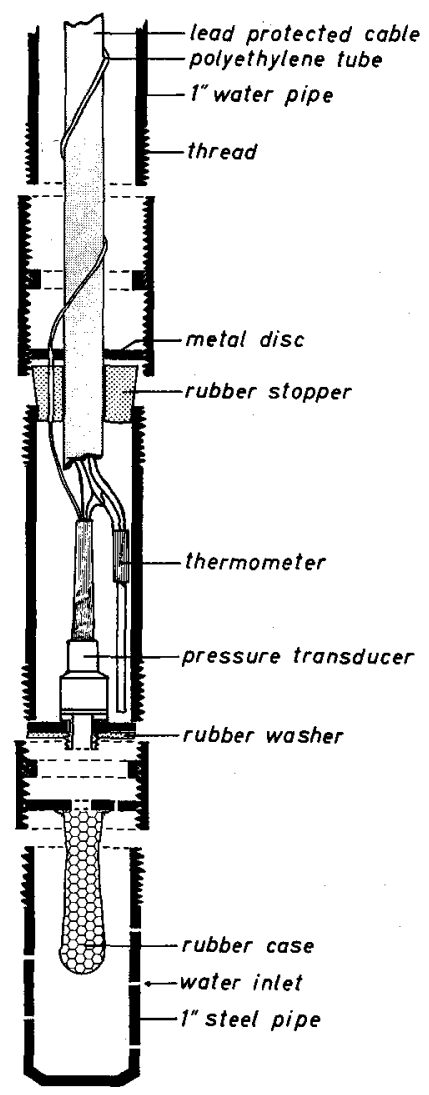




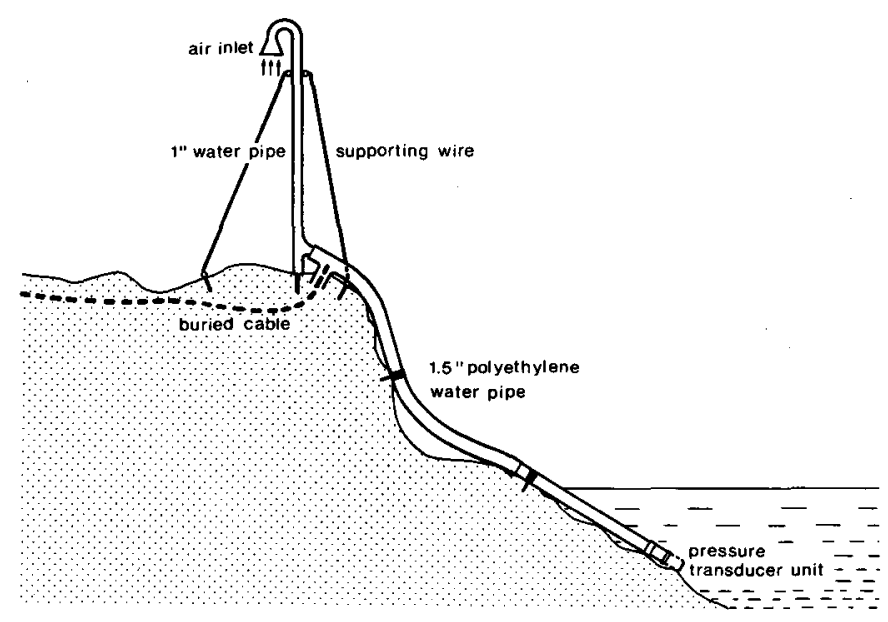

Fig. 18. Construction scheme showing a pressure transducer in operating position in a stream. The metal pole is approximately $3 \mathrm{~m}$ high.

Precipitation gauges (Nielsen et al., 1976) are connected, through a hole in the bottom, to a set of slightly modified pressure transducer units. In an attempt to reach higher accuracy of precipitation measurements, especially those of snow, a snow shield has been mounted on top of each gauge. This equipment has kindly been provided by the Danish Meteorological Institute. In early autumn a known amount of ethylene glycol was added to prevent formation of ice in the precipitation gauges.

A thermometer is included in each transducer unit and temperature is recorded in each series of measurements.

Modification of pre-existing pressure measuring membranes and construction of the transducer units have been undertaken by G. Asmund (GGU) and by the workshop of the Geological Central Institute, University of Copenhagen.

Measurements of the discharge of the rivers carried out during the field season are used to calibrate the signals stored on magnetic tape. Calibration is by discharge measurements made by means of a current meter and by the salt dilution method.

Measurements of precipitation are calibrated by measuring water depths in the gauges at intervals.

The results obtained by the dataloggers will serve two purposes: (1) They will comprise the main part of the hydrological and climatological work, especially during the winter seasons, and (2) they are to be used by the other disciplines involved in the Narssaq project.

The climatological data are now stored on computer paper tape and final treatment will be carried out as soon as results and calibration constants and equations are available from all 12 channels. The desired values (e.g. mean values of discharge for every month) and curves (e.g. variations of temperature at the ground surface) will then be produced with a high level of accuracy and low cost of time and manpower by computer. It will also be possible to use some of the parameters to calculate potential evaporation and air humidity. Results are expected to appear in the spring of 1978. 


\section{Geological mapping in the Narssaq intrusion, South Greenland (Dan Olsen)}

The area investigated is largely situated between a major E-W trending left-lateral fault and Narssap ilua. The unpublished observations of J. W. Stewart and B. L. Nielsen were of considerable use.

The main rock type is the Dyrnæs Syenite which comprises a variety of rather leucocratic porphyritic syenites, augite syenites and quartz syenites. At least 5 units are discerned. Each unit consists ideally of a thin feldspar porphyritic margin chilled against an earlier unit. The grain size of the matrix increases quickly away from the contact to produce a non-porphyritic rock composed of grey feldspar perthite having marginal zones of red microcline. At the same time the dark minerals cluster together in a synneusis fashion.

The individual units dip generally steeply WSW.

The westernmost unit deviates from the other units in being more homogeneous and in lacking any exposed porphyritic margin. The texture is dominated by tabular feldspars. The rock contains numerous indistinct dark layers, approximately $4 \mathrm{~cm}$ thick. These layers dip steeply ENE. Two small bodies of biotite gabbro with abundant inclusions of anorthosite occur within this unit. The contacts against the syenite are sharp and parallel to the contacts between the syenite units. The gabbro seems to be younger than the syenite.

The eastern part of the syenite complex is dissected by numerous, generally flat-lying, sheets of alkali granite, without common orientation. In addition, the intrusion is cut by numerous dykes of a regional ENE trend.

\section{References}

Bohse, H., Larsen, L. M., Rose-Hansen, J., Nielsen, C. O. \& Sørensen, H. 1975: Current research on the Ilímaussaq alkaline intrusion, South Greenland. Rapp. Grønlands geol. Unders. 75, 81-83.

Hansen, J. 1968: A study of radioactive veins containing rare-earth minerals in the area surrounding the Ilímaussaq alkaline intrusion in South Greenland. Bull. Gronlands geol. Unders. 76 (also Meddr Grønland 181, 8) $47 \mathrm{pp}$.

Nielsen, C. O., Rose-Hansen, J. \& Sørensen, H., 1976: Environmental, geochemical and ecological studies in the region around the Ilímaussaq alkaline intrusion, South Greenland. Rapp. Grønlands geol. Unders. 80, 93-97.

Weidick, A. 1963: Ice margin features in the Julianehåb district, South Greenland. Bull. Grønlands geol. Unders. 35, (also Meddr Grønland 165, 3) 133 pp.

Weidick, A. 1972: Holocene shore-lines and glacial stages in Greenland - an attempt at correlation. Rapp. Grønlands geol. Unders. 41, 39 pp.

J.A., H.B., N.P.C., J.J.,

S.K.-M., L.N., C.L.L.,

L.H.N., D.O., J.R.-H., H.S.,

Institut for Petrologi,

University of Copenhagen,

$\emptyset$ ster Voldgade 10,

1350 Copenhagen $K$.

S.F.,

Geologisk Museum,

Øster Voldgade 5,

1350 Copenhagen $K$.
H.M., P.M., B.H.N.,

Ferskvandsbiologisk Laboratorium,

Helsingørgade 49-51,

3400 Hillerød,

Denmark.

Institut for Almen Zoologi,

Universitetsparken 15 ,

2100 Copenhagen $\emptyset$.

J.F.,

E.S.,

Botanisk Museum,

Gothersgade 130,

1123 Copenhagen $K$.
Research Establishment, Risø, 4000 Roskilde, Denmark. 